\title{
Lexical review of disease names in the Udmurt language
}

\author{
Rebeka Kubitsch \\ University of Szeged
}

\section{Introduction}

This paper discusses the lexical review of the disease names in the Udmurt language. The paper introduces what kind of crosslinguistic tendencies occur in the naming of diseases, which factors can motivate the naming, what morphological features are typical for the disease names, and how all these features appear in the Udmurt language. The contacts of the names with other lexical areas are also mentioned.

Udmurt is a Uralic language, part of the Permic subgroup. It is spoken by ethnic Udmurts in the Russian constituent republic of Udmurtia, were it is co-official with Russian. According to Ethnologue (2010), there are 324,000 native speakers and the population of ethnic Udmurts is 554,000.

There is very little research on disease names and there is not much general literature about them. Furthermore, these sources introduce just a smaller part of the topic (and the authors are usually doctors, not linguists: for example, Berde 1940, who developed the folk approximation of the disease names). Galgóczi (1981) deals only with those names which have turned into curses or swear words. JääsalmiKrüger (1990) introduced the disease names of the Khanty language. Kicsi (1999) wrote about disease names that involve personal names or refer to causes, and, finally, Magyar (2000) discussed those disease names which have come from animals' names. In any case, there is no previous study on this topic with regard to the Udmurt language.

\section{Definition}

For the examination a definition was needed of what we can regard as a disease name. During my work I have treated as a disease name every expression which 
describes a pathological condition. A condition is pathological if an organ does not operate properly (Elekes 2010: 1). According to this definition it was problematic whether some symptoms (fever, cough), "aches" (headache, toothache) and cutaneous diseases (pimple, rash) could be considered as diseases. In the examination I treated them as such, ${ }^{1}$ because although a present speaker of the language would not consider a word like wound as a disease name, however, in this case some kind of aberration can be identified compared to the healthy condition.

Furthermore, it is quite a circumstantial (even impossible) exercise to define where the line is since an expression is not a symptom but a disease name. During this examination I did not make this separation because, in my opinion, the answer to this question depends on the individual user and there is no general solution. I do not consider important the distinction between symptoms and diseases, because I am examining folk terminology, not the technical, medical one. According to Frake (1980: 72), folk medicine always searches for the individual reason and event of the disease, hoping that by putting an end to the cause the problem will go away. Based on this, at the perception of a wound or pain the main question could be "What has caused this?" That is, certain symptoms have not been considered as traces of a disease, but, as I mentioned before, have been searched for their individual reasons.

\section{Corpus}

In the study 56 names of diseases are examined altogether. Some of these are from the book Votják népköltészeti hagyományok [Udmurt folk poetry traditions] by Bernát Munkácsi (1887), while others are names elicited from a native speaker. The corpus includes the names of general diseases (e.g. flu, diarrhea), many kinds of skin conditions (e.g. furuncle, rash), and illnesses causing epidemics (e.g. smallpox, dysentery) are included. Further names of diseases were included on the basis of naming patterns in Hungarian and other languages. For the analysis I used the dictionaries of Bernát Munkácsi (1896) and István Kozmács (2002) and the assistance of a native speaker (Ekaterina Suncova, Udmurt instructor at the FinnoUgric Department, University of Szeged)

\footnotetext{
${ }^{1}$ However, I treated them such that I did not collect all of the variants of "aches" in the Udmurt language. On the one hand because I will fully introduce their construction later, and on the other hand, by analogy we can "create" several disease names, but the aim of the study is not to collect more expressions but to introduce the naming patterns.
} 
During the lexicological research I did not take into consideration which dialect the word belongs to.

\section{Lexicological research}

During the lexicological analysis I have examined the following features: (1) whether the basis of the naming is a metaphor or a metonymy; (2) whether the name focuses on the cause or the symptom of a disease; (3) whether the disease name is expressed with a stem, a derived noun or compound word; (4) whether there is evidence of contact with other lexical fields. In this study I do not discuss all 56 disease names, only examples of all the types.

The disease names in the folk medicine are predominantly based on substitution. This is connected mainly to taboos, because diseases were considered as deviant, sickening phenomena in most of the cases, and speaking about them was considered inappropriate (even nowadays we can observe this attitude among the speakers regardless which language they speak). This is the reason for the metaphorical and metonymical nature of disease names. Furthermore, it is a universal tendency in the languages of the world that an abstract phenomenon is expressed with the help of the lexemes of more concrete conceptual fields (Kövecses and Benczes 2010: 91). In addition to folk medicine, beliefs are important in the naming of diseases as well.

\subsection{The metaphorical transfer}

The use of a metaphor generates a substitution between two different objects or phenomena according to analogy and/or similarity (Szathmári 2008: 309). During the metaphorical transfer the identifier (a concrete entity) and the identified (an abstract entity) originate from two different, "distant" points of our conceptual system (Kövecses and Benczes 2010: 93). In addition, the identifier has an earlier, more evidential meaning, which can be connected to basic physical experiences (because of this it could be even an identifier) (Szikszainé 2007: 428).

Among disease names, the metaphorical ones represent the oldest layer (Magyar 2000: 162). It is quite common that these names are linked to the names of animals, plants or everyday objects. To this can be connected the belief that creeping animals (snakes, frogs, beetles, spiders) sneak into the human body through orifices and cause many kinds of problems (Magyary and Kossa 1929: 285-287). Here are some Hungarian examples: the frog which disturbs the belly (there is a Hungarian saying, according to which if someone drinks too much water, béka nö a hasában 'a frog grows in his/her belly'), or the beetle which moves in the head and causes 
disturbance (another Hungarian saying is that if someone behaves in a strange way, bogara van "he/she has a beetle"). Another reason for metaphorical transfer is the above mentioned universal tendency that people tried to explain unfamiliar events or processes with the known environment, for example they compared the outer or inner attributions of an animal to the attributions of a disease (Kuna 2010). For example, English chickenpox ("chicken + pox"), Finnish vesirokko 'chickenpox" ("water + pox") and Hungarian bárányhimlö 'chickenpox' ("lamb + pox"). The analogy is the same in all three names: the words chicken, vesi and bárány refer to the fact that this kind of pox is less dangerous than the others (e.g. smallpox), since chickens, water and lambs are harmless, so the attribute of these things are similar to the attribute of the disease.

In the Udmurt corpus ten items were based on a metaphor. These are the following: гижло ("nail" + nmlz ) 'eczema, ringworm, scabies'; горд пужы ("red" + "freckle embroidery”) 'rash'; гыжло 'sty'; дыж 'cataract'; курег син ("hen" + “eye”) 'callus, glaucoma'; nomoc (“come out” + nmlz) 'carbuncle'; nужbl 'measles'; пуэд (“tree” + nmlz) 'eczema, ringworm, scabies';flu'; paк 'cancer’; сьӧдкилль ("black” + "infectious disease”) 'pox, typhoid fever'.

Of these expressions, I will discuss the following disease names in detail: гижло 'eczema, ringworm, scabies', горд пужы 'rash', дыж 'cataract', курег син 'callus, glaucoma'.

The basis of the name гижло 'есzema, ringworm, scabies' is the word гижь 'claw, nail' (Kozmács 2002: 90). The element -ло is a nominalizer, which is presumably used in dialects ${ }^{3}$ (personal communication, Ekaterina Suncova, 2015). On eczematous skin pimples with a dry, scaly and hard surface can occur, and in some cases the skin can cornify by degrees. The basis of the metaphor is that the touch of these pimples is similar to the hardness of nails. As we can see, the word has many meanings: in fact this word can be used for every type of skin disease when the pimple surfaces are hard.

In the name горд пужы ("red + freckle, embroidery") 'rash' the color name refers to the color of the rash. As we can see, the word nyжbl has several meanings: 'freckles, embroidery, pattern, measles' (Kozmács 2002: 353). The basis of the metaphor is the similarity between the arrangement of the rashes and freckles. In

${ }^{3}$ I base my presumption on the fact that Csúcs (1990) mentions the most important nominalizers, which are basically typical of the literary language, and among these it does not occur. 
addition, the pimply or freckled skin can look like embroidery or pattern. This is supported by the 'measles' meaning of the word.

The primary meaning of $\partial ы љ$ 'cataract' is 'shell, thin skin, membrane'. The origin of the naming is the same as in the Hungarian disease name (cf. Hungarian hályog in the sense of 'membrane, bladder'), namely, the idea that a membrane covers the eye and this causes the visual impairment. The basis if this idea is the fact that during this disease eyes look as if a thin skin covered them.

In the case of курег син ("hen" + "eye") 'callus, glaucoma' the metaphor originates from the formal similarity between the skin disease and the organ of the animal. In the middle of the typically round calluses a protrusion can be seen, so it is reminiscent of an eye. The same basis for the name of the condition occurs in Hungarian and other languages too (German Hühnerauge; French oeil de poule; Italian occhio pollino). The reason for this is that the expression is the calque of the Medieval Latin oculus pullinus (oculus 'eye'; pullinus 'hen') (Magyar 2000: 175). The other meaning of курег син is 'glaucoma'. The base of this naming is that one symptom of the glaucoma is that the lens of the eye becomes progressively opaque, resulting in blurred vision. When this happens the eye looks like the eyelid of a chicken.

\subsection{Metonymical transfer}

In metonymical transfer the connection between two phenomena is always a logical correlation. In this case instead of the conventional phrase we use a term which originally refered to the denomination of another thing. (Szathmári 2008: 410), Furthermore, in metonymical transfer the identifier (the concrete entity) and the identified (the abstract entity) originate from the same area of our conceptual system (Kövecses and Benczes 2010: 76).

In most cases the contiguity between two phenomena is a spatial or causal relation. A good example for the spatial connection is when a nation's typical disease (e.g. which occurs typically in a certain country or among the members of a certain nation) is named after the name of the nation (Kuna 2010). The Finnish espanjantauti ("Spanish" + "disease") 'Spanish flu' represents this type. The Spanish flu is the name of a special sort of flu which has caused the most destructive worldwide epidemic. The basis of the name is that the first news regarding the disease in 1918-19 came from Spain. A causal connection occurs if the disease is named after one of its causes or consequences, for example, Hungarian teniszkönyök ("tennis" + "elbow") 'tennis elbow'. The special inflammation in the elbow is 
typical of tennis players. Because of this it is named after the sport which causes the condition.

In the Udmurt corpus 19 items were based on metonymy. These are the following: берган кыль ("rotation" + "infectious disease") 'mad cow disease'; бульк 'a kind of disease connected to eating too much; disease causing spirit'; гордак ("red" + nmlz) 'measles'; дэй 'serious disease, hernia, disease causing spirit'; калера 'infectious disease, plague, cholera'; кӧт кыль ("belly, stomach" + “infectious disease”), 'diarrhea, dysentery'; кыль 'infecious disease, evil spirit'; кыльдэй ("infectious disease" + "infectious disease") "infectious disease, disease causing spirit'; кынмон (“cold" + nmlz) 'cold”; кырыюж кук (“crooked" + "leg”) 'rickets'; мыю 'gland disease, disease causing spirit'; ныр вия ("nose" + "flow") 'cold'; nӧськы ("hot" + derivational suffix) 'pimple, rash'; синтэм (“еуе" + car) 'cataract, blind'; сьӧдун ("black" + nmlz) 'rickets'; сюлэм чер ("chest + disease") 'chest disease'; чер 'serious disease, infection, bad, disease causing spirit'; ӥужектон (“sallow" + nmlz) 'jaundice'; blмnотос ("mouth + carbuncle”) 'angina, herpes'.

Of these expressions, I will discuss the following disease names in detail: бульюк 'a kind of disease connected to eating too much, disease causing spirit'; калера 'infectious disease, plague, cholera'; кыль 'infecious disease, evil spirit'; кыльдэй 'infectious disease, disease causing spirit'; пӧськьl 'pimple, rash'; синтэм 'cataract, blind'.

The name бульк 'a kind of disease connects to eating too much, disease causing spirit' expresses the disease and the spirit which causes the disease (personal communication, Ekaterina Suncova, 2015). In certain dictionaries the meaning 'pox, rash' is given, for example it can be found in compound words: пушнер булькк ("nettle" + "pox") 'hives'. The basis of the metonymy is the causal connection, which in the disease is named after the putative causer. It is presumable that one kind of meaning adhesion has happened, because there is also a separate expression for the causer of this type of disease: булькк пери 'disease causing, evil spirit' (Kozmács 2002: 48).

The word калера 'infectious disease, plague, cholera' is obviously the borrowing of the Russian холера 'cholera', but it has other connotations in the Udmurt language. In this case we can speak about a metonymical extension, because besides the 'cholera' meaning it is used in the more general sense of 'infectious disease'. The basis of the metonymy is that the name of a concrete disease is widened to refer to the a type of disease. 
The disease name кыль 'infectious disease, evil spirit' is also used in a general sense. This happens to almost every kind of infectious or serious disease (see above, берган кыль ("rotation" + “infectious disease") 'mad cow disease'; кӧт кыль ("belly, stomach" + "infectious disease") 'diarrhea, dysentery'). The basis of substitution is that the disease name is referred to with the name of the cause. In this case the importance of beliefs in folk medicine can be seen and in the second paragraph mentioned "searching for reason" attitude shows up too. The compound word кыльдэй 'infectious disease, disease-causing spirit' is connected to this lexeme. The first part of the construction is the above mentioned кыль, while the other is $\partial э \breve{u}$ 'serious disease, hernia, disease causing spirit'. As can be seen, both words have similar meanings (both meanings are general and express the causer spirit), and the compound's meaning is the same like its elements. According to Munkácsi's dictionary (1896: 164), кыльдэй is a spirit, which demands sacrifices from people at abandoned places. The basis of the metonymy is the same as in the previous case - the disease name is substituted with name of the spirit. All names introduced in this paragraph, derived from their 'evil spirit' meaning, are quite archaic.

The stem of the word nöcbкbl 'pimple, rash' is nöcb 'hot'. The element $-\kappa b l$ is presumably a derivational suffix (personal communication, Suncova 2015). ${ }^{4}$ The basis of the metonymy is that the disease is named after a symptom, because the inflamed skin is much warmer than its environment.

In this chapter the last introduced disease name is синтэм 'cataract, blind'. The meaning of син is 'eye' and -тэм is a very productive caritive suffix (Csúcs 1990: 59), so it literally means "the one without eyes". The basis of the metonymy is the experience that if someone has cataract (s)he can't see (or only very poorly) - the name of the disease is substituted with the name of the body part in question. The same is valid for the word's other meaning, 'blind'. Figure 1 below summarises the results.

\footnotetext{
${ }^{4}$ Regarding to the exact meaning of $-\kappa b l$ there is no further information.
} 


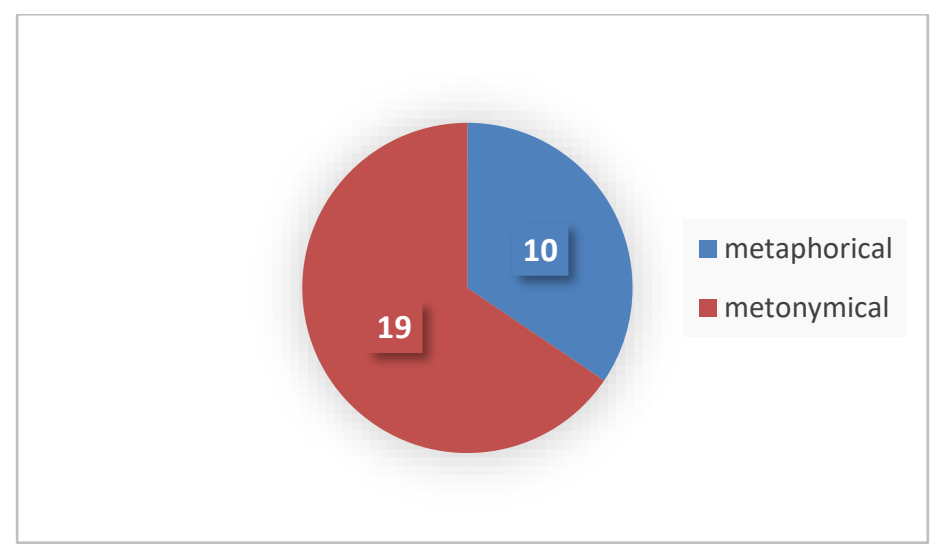

Figure 1

The distribution of metaphorical and metonymical disease names

\subsection{Cause- and symptom-focused disease names}

The essence of the cause- and symptom-focusing attitude is that during the naming process the disease is identified according to the actual or putative cause, or according to one of its typical symptom. ${ }^{5}$ Berde (1940: 95-6) has noticed this phenomenon during his research into folk dermatology. Although Berde has made these statements about folk dermatology, they are also valid for everyday approximation of disease names (Kicsi 1999: 108). For example, the English cold 'cold, sniffle' is a cause-focused disease name, because the problem is named after its cause. But Hungarian sárgaság ("yellow" + "nmlz") 'jaundice' disease name focuses on the symptom, because jaundice is a typical symptom of hepatitis. ${ }^{6}$

Depending on which type of disease name predominates in a given language it can, then, be labeled as cause- or symptom-focusing one. For example, in the 1940's

\footnotetext{
${ }^{5}$ It is important to mention that although there is a causal connection in the cause- or symptom focusing attitude, a cause- or symptom-focused disease name is not automatically a metonymical one. The type of the attitude is also identifiable among the metaphorical disease names.

${ }^{6}$ The cause- or symptom-focused approach is not identifiable in the case of every disease name. This can have many reasons: the word form cannot be segmented, there is not enough information about the etymology, and in the localizing compounds (4.4) none of the approximations prevail, because the localization helps in the identification of the disease, and is not the reference to its cause or symptom.
} 
Berde identified the Hungarian disease approach as a cause-focusing one (Berde 1940: 84), but Kicsi in 1999 claimed it to be symptom-focusing (Kicsi 1999: 190).

The phenomenon which was mentioned in 4.2, namely, when the disease is named after the causer spirit, also belongs to the cause-focusing aspect. This mentality is one of the reasons for the archaic nature of cause-focused disease names.

Below, I will discuss the disease names analysed in chapters 4.1 and $\mathbf{4 . 2}$ according to the cause- and symptom focused aspect.

From the metaphorical group, гижло 'есzema, ringworm, scabies', горд пужы 'rash' and курег син 'callus, glaucoma' are symptom-focused. The explanation is obvious: in the case of name гижло 'eczema, ringworm, scabies' a hard surfaced peeling is a typical symptom of this skin disease; in the case of name горд пужы 'rash' the name shows the colour and arrangement of pimples which are obviously the symptoms of the disease; and in the case of name курег син 'callus, glaucoma' as has been mentioned before, the distinctive mutation on the feet is the symptom of the problem. Nevertheless, дыж 'cataract' is a cause-focused disease name, because the name shows the putative source of visual impairment, that is, a membrane covering the eye.

From the metonymical group, бульк 'a kind of disease connected to eating too much, disease causing spirit', кьль 'infectious disease, evil spirit', and кьльдэй 'infectious disease, disease causing spirit' are cause-focused names, because, as has been mentioned before, they are named after the causing spirit.

From this group пӧськьl 'pimple, rash' and синтэм 'cataract, blind' are symptom-focused disease names. In the case of name nöcbкbl 'pimple, rash' it is obvious that the warm skin surface is the symptom of the inflammation, and in the case of name синтэм 'cataract, blind' the loss of vision is the consequence of the disease.

In the Udmurt corpus altogether nine items were cause-focused and 19 items were symptom-focused (Figure 2). Of the cause-focused names only one was metaphorical, eight were metonymical, while of the group of symptom-focused names five were metaphorical, and 14 were metonymical. 


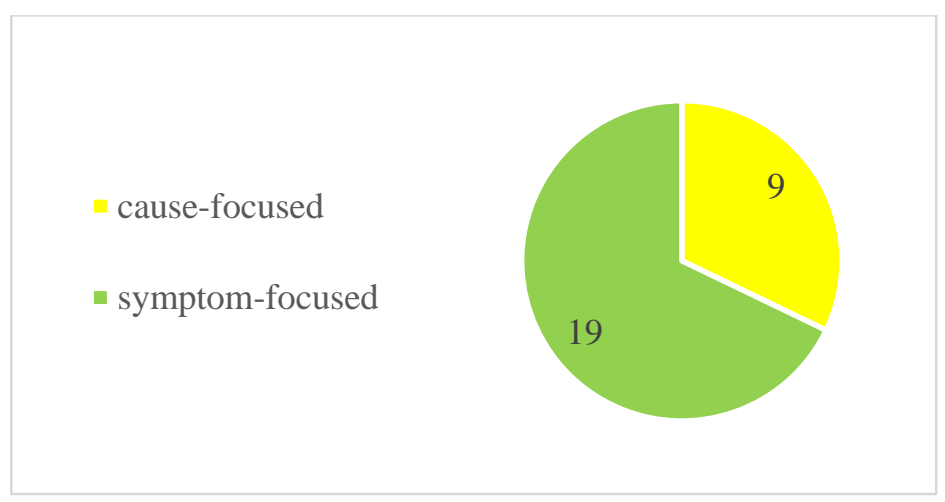

Figure 2. The distribution of cause-and symptom-focused disease name

\subsection{Morphological features}

The items of the corpus were classified according to the morphological structure of the lexemes: stems, derived words and compound words.

In the Udmurt corpus 13 stems occurred. Most frequently their meanings are 'disease' or 'wound', for example: мыю 'gland disease, disease-causing spirit'; шек 'serious wound'; чер 'serious disease, infection, bad, disease causing spirit'; яра 'eczema, ulcer, deep wound'. In several cases either the motivation of the naming process or the prevailing approximation cannot be identified. However, these stems quite often occur in compounds (сюлэм чер 'chest disease', сюлпуш яра 'stomach ulcer, duodenal ulcer').

In the corpus 13 derived words were found. In section 4.1 and 4.2 I have mentioned most of the derivational suffixes. In addition, the nouns derived from verbs are the most common, whereas disease names derived from nouns or adjectives are less common.

The most productive derivational suffix is $-\mathrm{OH} /-\ddot{e} H$ deverbal nominaliser, which derives nouns from abstract verbs (Csúcs 1990: 59), for example, кынмон 'cold' from the verb кынмыны 'chill', or ӥужектон 'jaundice' from the verb ӥужектыны 'sallow'.

The -oc/-ëc derivational suffix, which occurs in nomoc 'carbuncle', is less frequent. In addition the meanings of two more derivational suffixes could be identified exactly: the caritive suffix $-т э \kappa$ (Csúcs 1990: 59) and $-a \kappa /-я \kappa$, which expresses a reduced owning of an attribution (personal communication, Ekaterina Suncova, 2015). In the other cases, -эд/-ед (пуэд 'flu' - “tree” + nmlz), -ло (гижло 'eczema, ringworm, scabies' - 4.1), -кbl (пӧськь 'pimple, rash' - 4.2) and -yн 
( сьӧдун 'rickets' - "black" + nmlz) the meanings of the derivational suffixes are not sure. In many cases these disease names were the only examples for the use of these derivational suffixes.

In the corpus 19 disease names are expressed with compound words. It is typical that a word joins to a 'pain, bad, wound, disease' meaning word (Jääsalmi-Krüger 1990: 9). Within this, a subgroup can be identified, that of localizing compound words. In this group the disease name somehow localises the source of the problem. The composition 'body part' + 'disease, ache' is the most frequent in general (e.g. headache, brain tumour) (Kuna 2010).

Udmurt сюлдэй 'gripes, diarrhea' is a good example of localizing compound words. The first part of the compound is сюл 'gut', while the second is the above mentioned $\partial э \check{u}$ 'serious disease, hernia, disease-causing spirit' (4.2). The disease name identifies the location of the problem, because this type of disease concerns the gut. In the Udmurt corpus 9 of the 19 compound words were localizing.

It is not uncommon that the name of an animal, plant or color is compounded with the word meaning 'disease, ache' (for an explanation, see chapter 4.1), for example, chickenpox and red measles.

In the corpus there were 13 stems, 13 derived words and 19 compound words altogether (Figure 3).

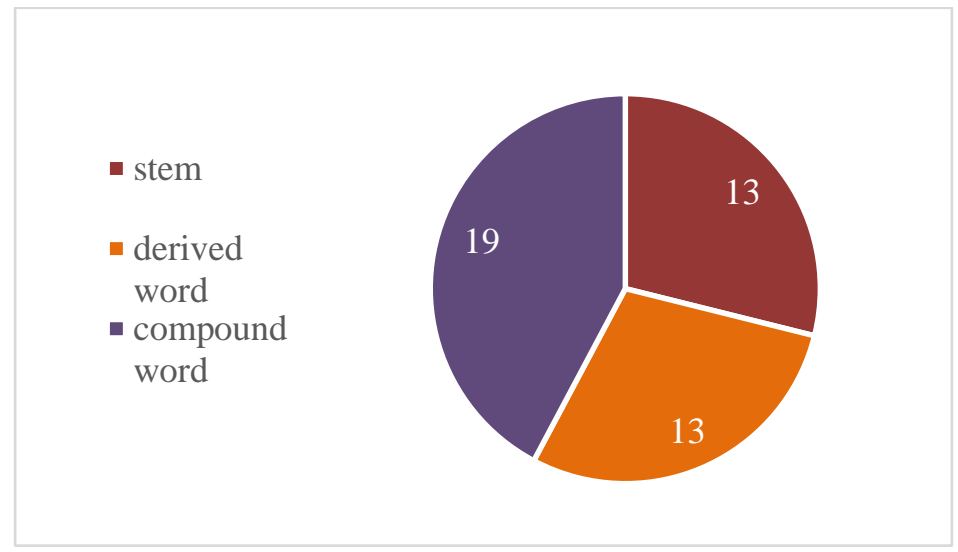

Figure 3. Morphological features

\subsection{Unidentified disease names}

From the Udmurt corpus a total of 12 items were not examined. The reason is that there was not enough information about either the motivation of naming or the 
morphological characteristics. Among the 12 disease names seven items are of Russian origin. These words have been left in the corpus because in spite of their foreign origin, they are used in the Udmurt language. However, I did not examine them because they do not have any further meaning in Udmurt. The disease name калера 'infectious disease, plague, cholera' is an exception, because it has further meaning ('infectious disease') in addition to the original one (4.2).

\subsection{Contacts with other lexical fields}

There's a contiguity between the lexical field of disease names and the group of animal, plant and color names. Examples are mentioned in chapter 4.1, and the reasons of connection are explained as well. In addition, this lexical field often contacts with the field of body parts, mainly in compound words, because of the claim of localization (4.4). The group of several kinds of gods, spirits names is frequently appears among the contacts, too. This connects to the belief that diseases are sent by gods or spirits $(\mathbf{4 . 2}, \mathbf{3})$. The lexical fields mentioned in this paragraph are the most typical of the naming of disease names.

Nevertheless, we have to take into consideration those lexical fields too which name their elements after disease names. During the research two such groups were identified. The first is the group of plants names, the other is the group of metaphorical, idiomatic expressions. Into the group of plants names usually the names of herbs are involved. It is a frequent phenomenon, not only in Udmurt that a herb is named after the disease it cures. For example, the Udmurt кӧткыльсяська ("diarrhea, dysentery" + "flower") 'silverweed', which is used for diarrhea, intestinal bleeding, and other kinds of stomach diseases. Or бульктурын ("a kind of disease connected to eating too much, disease-causing spirit" + "herb") 'salsify', which can ease stomach ache, so it could (or still can) be used to cure this kind of problem.

The usage of disease names in metaphorical, idiomatic expressions is the topic of another paper (Kubitsch 2015). 


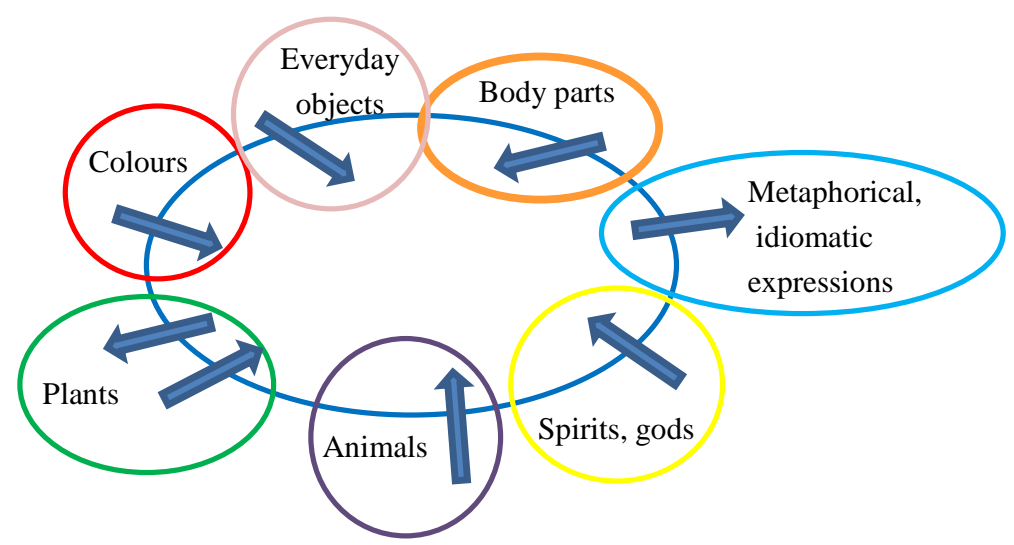

Figure 4. Contacts with other lexical areas

\section{Conclusion}

In the lexicological research reported on in this paper altogether 56 disease names were examined. Although the research cannot be considered exhaustive, some - in my opinion general - features of the naming methods and the morphological structures can be identified, for example, the predominance of metonymic disease names compared to the metaphorical ones. Of the 56 disease names, in 29 cases the basis of the naming could be identified. Of these 29 items 19 were metonymic and ten disease names were metaphorical (Figure 5). In my opinion the predominance of metonymic disease names is a general phenomenon in the Udmurt language and similar results would be found in a bigger corpus as well. I think that the reason for this is the development of medicine - during the identification of a disease its similarity to a well-known thing is less important, we rather identify it according to causal connections. As Magyar (2000) remarked, metaphorical names represent the oldest layer of disease names.

Another general phenomenon is that the symptom-focused names are more common than the cause-focused ones. This is true the metaphorical and metonymic disease names as well (4.3). In the corpus in 28 cases was the disease approach identifiable. Of these, in nine cases the approximation is cause-focusing and in 19 cases it is symptom-focusing (Figure 6). I have mentioned before that the causefocused names are usually archaic (4.3) and the cause seeking attitude is typical of folk medicine (chapter 2). Because of the development of medicine this need fades away and preferably we focus on the symptoms during the identification of a disease. That is why I think that the predominance of symptom-focused names 
would be the same in a bigger corpus too. Thus, it might be plausible to claim that the Udmurt disease approximation is symptom-focusing just like the Hungarian.

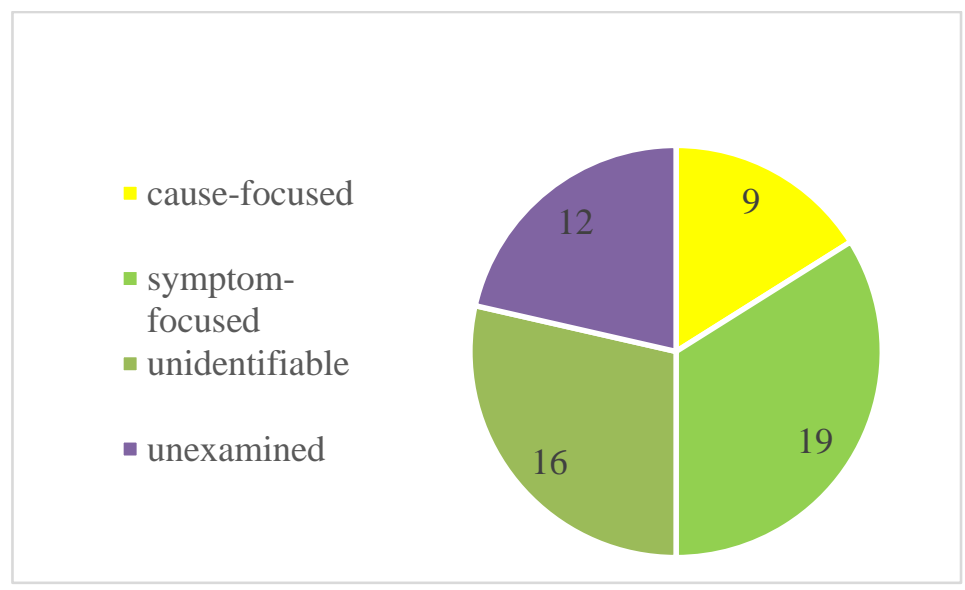

Figure 6. The cause- and symptom focused disease names

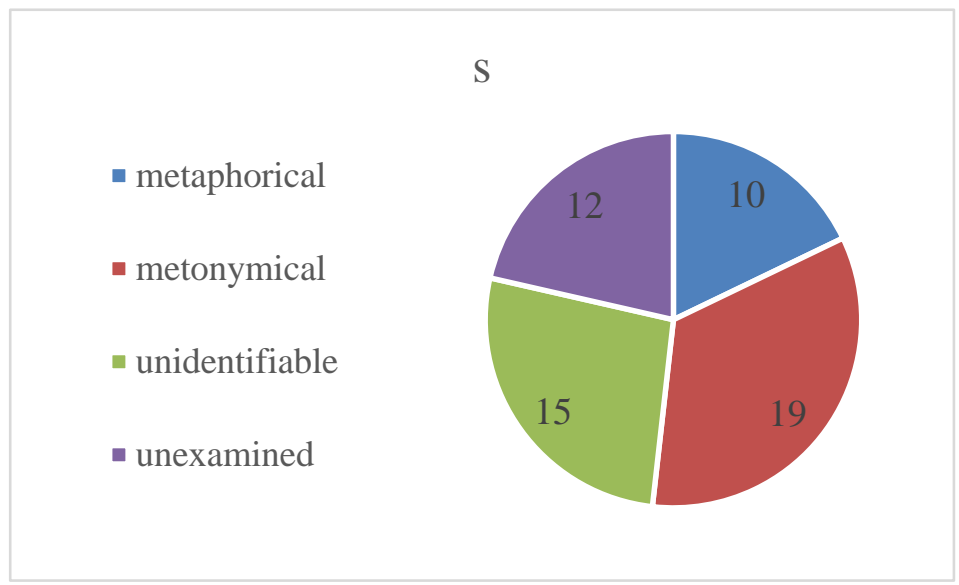

Figure 5. The metaphorical and metonymic disease names

Among the morphological features the dominance of compound words has been observed. The morphological structure could be identified in 45 cases. Of these, 13 were expressed with stems, 13 were derived words, and 19 compound words (Figure 
7). Among the compound words nine items were localising compounds (Figure 8). We can see that the claim of localization is quite strong. In my opinion in a bigger corpus the proportion of localising compounds would be very similar. It is also important that in many cases neither the disease approximation nor metaphorical or metonymic based naming could be identified among the localising compounds. The reason could be that in these cases the localising helps in the identification, but it is not necessary that we identify it according to its similarity to something or according to its cause or symptom.

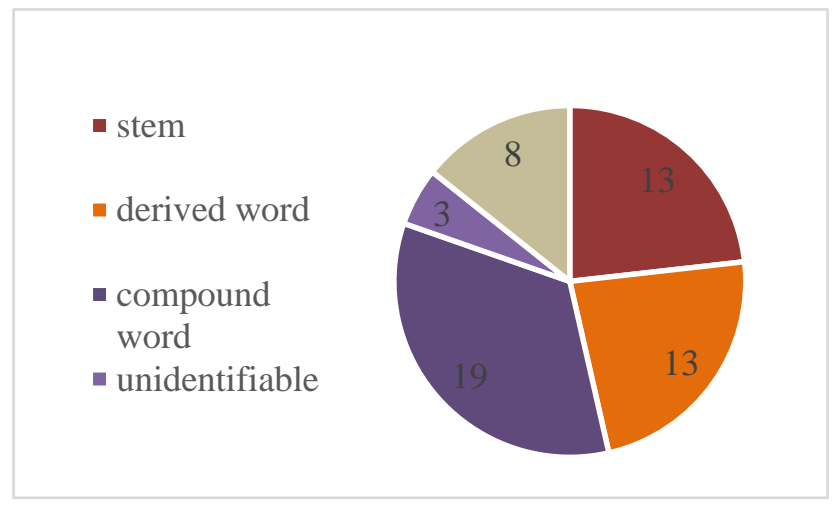

Figure 7. Morphological features

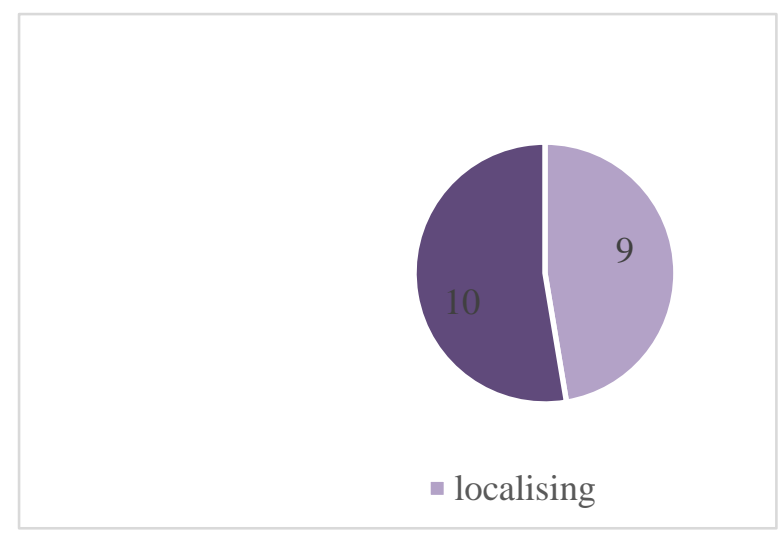

Figure 8. Localising and other compounds 
Abbreviations

CAR Caritive

NMZL Nominalizer

\section{References}

Berde, Károly 1940. A magyar nép dermatológiája [The dermatology of the Hungarian people]. Budapest: Magyar Orvosi Könyvkiadó Társulat.

Csúcs, Sándor 1990. Chrestomathia Votiacica. Budapest: Tankönyvkiadó.

Elekes, Zsuzsanna 2010. Egészségkárositó magatartások és mérési módszerek [Health endangering behaviors and methods of measurement]. www.tankonyvtar.hu

Ethnologue 2010. http://www.ethnologue.com/language/udm

Frake, Charles 1980. Language and cultural description. Stanford: Stanford University Press.

Galgóczi, László 1981. Szitokszóvá vált betegségneveink [Disease names that became curse words]. Magyar Nyelv 77: 188-196.

Kozmács, István 2002. Udmurt-magyar szótár [Udmurt-Hungarian dictionary]. Szombathely: Savaria University Press.

Jääsalmi-Krüger, Paula 1990. Ostjakische Krankheitsnamen und deren Benennungmotivation. Eine onomasiologisch-semasiologische Untersuchung. [Khanty disease names and motivation of their naming. An onomasiologic-semasiologic examination.]. (Dissertation). Wiesbaden: Veröffentlichungen der Societas Uralo-Altaica 32.

Kicsi, Sándor András 1999. A hagyományos magyar népi okcentrikus betegségszemléletről [On the traditional Hungarian cause centric view of diseases]. Orvostörténeti közlemények 166-169: 107-119. www.orvostortenet.hu/tankonyvek/tk05/pdf/4.25/1999_166_169_kicsi_sandor_hagyomanyos_magyar.pdf

Kubitsch, Rebeka 2015. The metaphorical usage of disease names in the Udmurt language, National Students' Scientific Conference, Budapest. ms.

Kövecses, Zoltán and Benczes, Réka 2010. Kognitív nyelvészet [Cognitive Linguistics]. Budapest: Akadémiai Kiadó.

Kuna, Ágnes 2010. Szent Antal tüzétől a Münchausen-szindrómáig [From St. Anthony's fire to the Munchausen's syndrome]. 
http://e-nyelvmagazin.hu/2010/12/06/szent-antal-tuzetol-a-munchausenszindromaig-\%E2\%80\%93-regi-es-a-modern-betegsegneveink-nehanyjellegzetessege/

Magyar, László András 2000. Állatok és betegségnevek [Animals and disease names]. Orvostörténeti közlemények 170-173: 161-177.

www.orvostortenet.hu/tankonyvek/tk-

05/pdf/2.13/2000_170_173_magyar_laszlo_allatok_betegsegnevek.pdf

Magyary-Kossa Gyula 1929. Magyar orvosi emlékek II [Hungarian medical records II] Budapest: Eggenberger-féle Könyvkereskedés.

Munkácsi Bernát 1990. A votják nyelv szótára [A dictionary of the Votyak language]. Az Uralisztikai Tanszék Kiadványai 1. Pécs.

Munkácsi Bernát 1887. Votják népköltészeti hagyományok [Votyak folk poetry traditions]. Budapest: Magyar Tudományos Akadémia.

Szathmári István 2008. Alakzatlexikon [A dictionary of figures of speech]. Budapest: Tinta Könyvkiadó.

Szikszainé Nagy Irma 2007. Magyar stilisztika [Hungarian stylistics]. Budapest: Osiris Kiadó. 